zeventig werden weggewerkt veelzeggend zijn voor het emancipatiegehalte van de betrokken huisvrouwen, wordt door De Rijk tot twee maal toe met stelligheid beweerd, maar hij toont het nergens aan.

Het elektrische huis is geen vlot leesbaar boek, vooral door de slordige formuleringen en het droppen van informatie zonder nadere inkadering of interpretatie. De vele tussenkoppen één, soms twee per pagina—komen de helderheid van het betoog niet ten goede. Ook ontbreekt een conclusie. Het laatste hoofdstuk bevat veertien samenvattingen, zonder rode draad. Dat is te begrijpen. De Rijk formuleert behalve talloze deelvragen — de meeste per bedrijf — alleen een globale aanpak.

De bedrijfshoofdstukken bieden zeker waardevolle gegevens over de introductie en vormgeving van nieuwe huishoudelijke apparatuur. Maar voor het tweede deel van de ondertitel, de acceptatie, is het wachten op een verdere uitwerking. Wat deed Philips bijvoorbeeld met het ergonomisch onderzoek uit 1961 naar het staand strijken? Ook over de rol van vrouwen in de productie en propaganda van huishoudeüjke apparaten biedt het boek vooral voorzetjes. Een aardige staat op pagina 313. De Philipsvestiging in Drachten stelde een elektro-huishoudkundige aan om zich een 'typisch vrouwelijk' oordeel te vormen over de doelmatigheid van huishoudelijke apparatuur. De bijbehorende noot vermeldt dat mej. J. Poelstra in eenzelfde functie werd aangesteld, hetgeen de Philips Koerier in 1965 deed verzuchten: 'Eén Drachtster vrouw is vele technici te erg'. Zo'n opmerking maakt mij als naamgenote en toenmalig inwoonster van Drachten natuurlijk nieuwsgierig. Maar wat ik vooral wil weten: wanneer en waarom schakelden de producenten van huishoudelijke apparatuur vrouwen in? En waren ze, behalve als lopende bandmedewerkster en propagandiste, ook actief als producente en ontwerpster?

\title{
Jannie Poelstra
}

C. A. Lee, Anne Frank 1929-1945. Pluk rozen op aarde en vergeet mij niet (Amsterdam: Balans, 1998, 352 blz., f39,50, ISBN 905018532 0); M. Muller, Anne Frank. De biografie (Amsterdam: Bert Bakker, 1998, 306 blz., f39,90, ISBN 903511990 8).

Anne Frank werd geboren in Frankfurt am Main op 12 juli 1929. Zij stierf in maart 1945 (de precieze datum is niet bekend) in het concentratiekamp Bergen-Belsen. Sinds begin 1934 had zij in Amsterdam geleefd, van juli 1942 tot 4 augustus 1944 in het later zo beroemd geworden achterhuis van Prinsengracht 263. Na de arrestatie in augustus 1944 verbleven de onderduikers korte tijd in Westerbork. Op 3 september 1944 werden zij naar Auschwitz gedeporteerd. Eind oktober werden Anne en haar zusje Margot naar Bergen-Belsen overgebracht. Moeder Edith stierf op 6 januari 1945 in Auschwitz-Birkenau. Vader Otto werd op 27 januari daar door het Rode Leger bevrijd. Geen van de andere onderduikers in het achterhuis overleefde de kampen. De dagboeken van Anne Frank, bijgehouden van 12 juni 1942 tot 1 augustus 1944, behoren tot de beroemdste en meest gelezen teksten ter wereld. Tot voor kort bestond van Anne geen biografie, het uit 1958 daterende boek van E. Schnabel wellicht uitgezonderd ${ }^{1}$. Enerzijds is dat niet verwonderlijk. Wat valt er immers nog te biograferen aan een meisje dat nog geen zestien jaar werd en over wie alle belangwekkende gegevens in haar vele malen herdrukte dagboeken en in de publicaties over en rond die dagboeken gemakkelijk voor iedereen te vinden zijn ${ }^{2}$ ? Anderzijds verbaast het juist wel, dat vijftig jaar na de eerste publicatie van die dagboeken in

1 E. Schnabel, Anne Frank. Spur eines Kindes (Frankfurt am Main, 1958).

2 De kern-publicatie is de wetenschappelijke editie van de dagboeken: H. Paape, G. van der Stroom en D. Barnouw, De dagboeken van Anne Frank (Den Haag, Amsterdam, 1986). 
1947, die zo beroemd werden ${ }^{3}$, niet ook een hele reeks biografische werken beschikbaar is. Het toeval wil dat aan die situatie een einde kwam in 1998, toen vrijwel gelijktijdig zelfs twee biografieën van Anne Frank verschenen, beide geschreven door een jonge vrouw. Carol Ann Lee (1969) en Melissa Müller (1967) lazen, zoals zovelen, de dagboeken in hun jeugd en werden er door gegrepen.

Lee en Müller stonden, zoals gezegd, voor een niet geringe opgave. Wat viel er nog toe te voegen en hoe van de beschikbare gegevens een volwaardige biografie te maken? Beiden zochten en vonden dezelfde, vermoedelijk enige begaanbare, uitweg. Waar aan de levensgeschiedenis van Anne niet veel was toe te voegen, moest het komen van plaatsing van die levensgeschiedenis in een bredere context: de familie en gezinsgeschiedenis van Anne, de entourage van Anne en het gezin Frank in Amsterdam, de jodenvervolging in het algemeen en meer specifiek in (bezet) Nederland, de concentratiekampen, de na-oorlogse belevenissen van de overlevenden onder de ten tonele gevoerde personen en de publicatiegeschiedenis van de dagboeken. Voor Anne zelf bleek een, in sterke mate op de dagboeken steunende, inlevende en psychologiserende aanpak de logische oplossing. Zonder grondigheid van onderzoek en onderbouwing van het verhaal op te geven, streefden beide schrijfsters ook naar een breed publiek en kozen dus een vlotte, leesbare en verhalende stijl.

Beiden zijn in hoofdzaak in hun opzet geslaagd. Zonder dat kenners veel nieuws of echt verrassends aantreffen, gaat het om zeer informatieve, in details wel degelijk af en toe nieuwe gegevens brengende, leesbare en over het algemeen betrouwbare biografieën. Zelfs de relatief kort gehouden achtergrondbeschrijvingen over Nederland, voor buitenlandse auteurs dikwijls lastig, zijn meestal behoorlijk, al valt er natuurlijk wel wat te muggenziften. Zo noteert Lee zonder verbazing dat er na de oorlog bij de bakker die het brood voor de onderduikers leverde eigenlijk nog een schuld zou uitstaan van $f 160.000$,-. Dat is bij een onderduikperiode van \pm 760 dagen meer dan $f 200$,- aan brood per dag voor acht personen! En Muller laat Colijn nog weer eens na het uitbreken van de Tweede Wereldoorlog in 1939 als minister-president(!) het Nederlandse volk verzekeren dat het rustig kon gaan slapen. Maar dat zijn uitzonderingen op de regel.

Bij zo'n gelijksoortige aanpak vallen de verschillen bij de overeenkomsten in het niet. Müller heeft relatief veel aandacht voor de familiegeschiedenis van de Holländers (de kant van Anne's moeder) met ook interessante, voor mij nieuwe foto's. Lee heeft vooral boeiend weten te putten uit de collectie Buddy Elias (een neef van Anne van vaders zijde, nog altijd een belangrijke man in het Anne Frank Fonds in Bazel) in het bijzonder voor de na-oorlogse periode. De stijl van Lee neigt soms tot babbelen, terwijl die van Muller af en toe quasi-gewichtig èn diepgravend wordt, bijvoorbeeld over wat gewoon puberfratsen zijn. Het notenapparaat van Lee is uitvoeriger en adequater. Hoewel ook Muller flink annoteert, maakt zij zich toch ook nogal eens schuldig aan beweringen zonder bronvermelding (bijvoorbeeld over gemoedstoestanden van personen). Daar staat natuurlijk tegenover dat Müller een regelrechte sensatie presenteerde: vijf nieuwe dagboekblaadjes.

In verband met het auteursrecht publiceerde Müller de blaadjes niet volledig, maar beperkte zich tot parafraseren. Het is niettemin een belangwekkende 'meerwaarde' van haar biografie. Het gaat in deze blaadjes vooral om een beschouwing van Anne over het huwelijk van haar ouders. Zonder daar echt wat van te weten, meent zij toch dat haar vader eigenlijk nooit zo diep en echt van haar moeder heeft gehouden als van een eerdere geliefde met wie het niet tot een huwelijk was gekomen. Anne ontleende aan deze 'wetenschap' een zeker mededogen met haar moeder, met wie ze overigens (zoals uit de dagboeken bekend) een zeer gespannen relatie

3 Voor diverse aspecten van deze beroemdheid zie bijvoorbeeld D. Barnouw, Anne Frank voor beginners en gevorderden (Den Haag, 1998). 
had. Het doet ook niet af aan de sterke band met haar vader. Uit historisch perspectief is het zeer jammer dat Otto Frank deze blaadjes buiten de publicatie van de dagboeken hield. Uit menselijk oogpunt is het wel begrijpelijk, zoals begrijpelijk is dat hij ook enkele andere passages, die wel bij de dagboeken die hij aan Oorlogsdocumentatie vermaakte zaten, uit de publicatie weerde. In de wetenschappelijke editie uit 1986 wordt wel aangegeven van welke datum en hoe omvangrijk die passages zijn. Het ziet er thans (mei 2000) naar uit dat binnen afzienbare tijd een nieuwe druk van de wetenschappelijke editie van de dagboeken zal kunnen verschijnen waarin zowel de oude weglatingen als de nieuw opgedoken blaadjes zullen zijn opgenomen.

Nog niet volledig opgehelderd is waarom Otto Frank deze vijf blaadjes, anders dan die andere passages, apart bewaarde en tegen het einde van zijn leven aan Cor Suijk overhandigde. Deze hield het bestaan van deze blaadjes geheim tot hij het aan Muller onthulde om er vervolgens ook zelf mee naar buiten te treden. Wat afstand nemend van de publicitaire sensatie, en zonder aan het bijzondere van deze 'vondst' te willen afdoen, kan overigens worden vastgesteld dat inhoudelijk gezien de kenniswinst niet erg groot is. Aan het beeld van Anne Frank en de relatie met haar ouders verandert eigenlijk niets. En als bron voor de aard van het huwelijk van Edith en Otto Frank (een curieuze vraag overigens van zeer beperkte historische betekenis lijkt mij) zijn deze blaadjes nauwelijks betrouwbaar te noemen.

Een ander punt waar Lee en Muller van elkaar verschillen is de vraag naar de verrader, de tipgever aan de Gestapo. Lee volgt de gangbare weg. Magazijnknecht Van Maaren is het zwaarst verdacht en alszodanig beschouwd en aangewezen. Maar zijn schuld is nimmer bewezen, dat wil in ons rechtssysteem zeggen: niet schuldig. Anders gezegd: we weten het niet. Muller geeft toe dat zij het ook niet weet, maar suggereert met enige nadruk de echtgenote van een andere magazijnbediende, Lena Hartog-van Bladeren, als tipgeefster. Dat is een creatieve wending (niet volstrekt origineel overigens, zij was wel al eerder terzijde besproken). Maar van een sterke bewijsvoering is geen sprake. In het bijzonder lijkt mij hier twijfelachtig dat de zinsnede over de telefonische tip 'hardnekkige geruchten spreken van een vrouwelijke stem' ongeannoteerd is gebleven. Meer in het algemeen valt op, dat de indruk van beide schrijfsters, dat de arrestatieploeg precies wist hoe en waar te zoeken, op het eerste gezicht strijdig is met het aanwijzen van niet-ingewijden als verdachten. En de magazijnbedienden zaten niet in het complot van de verzorgers, al konden zij allicht vermoeden dat er in het voor hen ontoegankelijke achterhuis onderduikers zaten. Hoe dan ook, de formulering van Harry Paape uit 1986 lijkt nog altijd adequaat: 'Dat dit Van Maaren is geweest, lijkt ons niet uitgesloten ... Dat het iemand anders is geweest achten wij minstens even waarschijnlijk. De juiste toedracht zal niet meer gereconstrueerd kunnen worden' (wetenschappelijke editie van de dagboeken, 53).

Eén opmerking tot slot. Na lezing van beide boeken viel mij in dat de eigenlijk interessante figuur om te biograferen Otto Frank is. In het bijzonder zijn leven na de Tweede Wereldoorlog kent een aantal aspecten die nadere behandeling verdienen. Hij was Anne's held en in zekere zin nemen beide schrijfsters dat van haar over. Ongetwijfeld was Otto Frank een bijzonder mens. Juist daarom verdient hij een biografie die hem in zijn sociale context neerzet en analyseert. Daarmee zal hij 'menselijker' worden, zoals zowel Lee en Müller Anne menselijker hebben beschreven dan in veel verheerlijkende publicaties gebeurt. Dat is een belangrijkste verdienste.

J. C. H. Blom

H. Knap, Forschungsstelle Langeveld. Duits afluisterstation in bezet Nederland (Amsterdam: De Bataafsche leeuw, 1998, 352 blz., f45,-, ISBN 906707467 5).

De belangstelling voor de geschiedenis van sigint als onderdeel van de geschiedenis van 